\title{
Effects of Cognition, Meta-Cognition and Social Affective Strategies through application of the module "Learning to Learn" in University Students
}

\author{
William Gil Castro Paniagua ${ }^{1}$, Abdias Chávez Epiquén ${ }^{2}$, Dulio Oseda Gago ${ }^{3}$ \\ ${ }^{1}$ Universidad Nacional José María Arguedas - UNAJMA. Jr. Juan F. Ramos, Andahuaylas 03701, Perú. ${ }^{2}$ Universidad Nacional \\ Ciro Alegría - UNCA. ${ }^{3}$ Universidad Nacional De Cañete - UNDC, Perú. \\ Author for correspondence: williamgilcastro20@gmail.com
}

\begin{abstract}
In the field of cognitive psychology, the study of learning and teaching strategies has aroused a growing interest. This work shows the effect of the application of a module called "learning to learn" applied to learn strategies in students of the second term of the National University of the Amazonia from Peru. The quantitative approach was used, the design was quasiexperimental and the instrument a self-reporting questionnaire. The sample was a group of one hundred twenty-three university students $(n=120)$. The effect of the module learns to learn does not present a significant improvement $(p>0.05)$ in the learning strategies. Maturation and internal motivation were factors that could explain this finding.
\end{abstract}

Keywords: Learning Strategies, Cognitive, Metacognitive, Social Affective Strategies. 


\section{Efeitos da Cognição, Meta-Cognição e Estratégias Sócio- Afetivas em Estudantes Universitários}

RESUMO. No campo da psicologia cognitiva, o estudo das estratégias de aprendizagem e ensino despertaram um interesse crescente. Este trabalho mostra o efeito da aplicação de um módulo chamado "aprender a aprender" aplicado a estratégias de aprendizagem em estudantes do segundo ciclo da Universidade Nacional da Amazônia do Peru. A abordagem quantitativa foi utilizada, o desenho foi quase-experimental e o instrumento um questionário de auto-relato. A amostra foi um grupo de cento e vinte e três estudantes universitários $(n=120)$. O efeito do módulo aprende a aprender não apresenta uma melhoria significativa $(\mathrm{p}>0,05)$ nas estratégias de aprendizagem. A maturação e a motivação interna foram fatores que poderiam explicar este achado.

Palavras-chave: Estratégias de Aprendizagem, Cognição, Metacognição, Estratégias Socioemocionais. 


\section{Efectos de las estrategias cognitivas, meta cognitivas y socio afectivas en estudiantes universitarios}

RESUMEN. En el campo de la psicología cognitiva el estudio de las estrategias de enseñanza y aprendizaje ha despertado un creciente interés. Este trabajo muestra el efecto de la aplicación de un módulo llamado: "Aprender a Aprender" aplicado en las estrategias de aprendizaje en los estudiantes del segundo ciclo de la Universidad Nacional del Amazonas en Perú. El método utilizado fue cuantitativo, el diseño cuasi experimental y los instrumentos aplicados fueron cuestionarios. La muestra constituyó de un grupo de ciento veinte estudiantes universitarios $(n=120)$. El efecto del módulo "Aprender a Aprender" no representó una mejora significativa $(p>0.05)$ en las estrategias de aprendizaje. La maduración y la motivación interna son factores que podrían explicar este hallazgo.

Palabras clave: Estrategias de Aprendizaje, Cognición, Metacognición, Estrategias socioemocionales. 


\section{Introduction}

In the process of cognition and storage of information when an individual learns a variety of cognitive mechanisms such as coding, retention, storage, retrieval, and the response of information are activated. These processes are activated from a set of cognitive structures (sensory registers or receptors, short-term memory, long-term memory, and expressive effectors or response generators), which occur in the central processor (human brain) through the strategies of learning (Atkinson \& Shiffrin, 1968). About the theoretical approaches in learning strategies, the postulates of Nisbet and Shucksmith (1987) and Weinstein, Goetz and Alexander, (1988) are assumed, and they say that the processes are flexible and enable an adequate use of learning strategies.

In researches about the training of learning strategies, has been strong growth, and the works of Braten and Olausen (1988) and Halbach (2000), are focused on identifying the learning strategies used by students. Similarly, Chamot (1987), Carr and Jessup (1995), Chalupa, Chen and Charles (2001) and Chen (2002), had researched in students the use of learning strategies in several contexts. Likewise, Ablard and Lipzchultz (1998), Bembenutty and Zimmerman (2003), have examined the influencing variables to the use of learning strategies in students. On the other hand, the findings obtained by Gargallo (2000), in the application of the training program in learning strategies in students of 1st and 2nd year of secondary school, in which he achieves the transference of learning strategies.

\section{Learning Strategies}

It is well known that students to achieve academic success always turn to different learning strategies. Some learning strategies may be beneficial for some but harmful for others, the choice of one type of strategy over the other has been extensively investigated in the last three decades (Neroni et al., 2019). Learning strategies are also seen as a process of acquisition, organization, and transformation of information to succeed in the study. It is very important to know how to study in a way that lasts the knowledge and skills acquired, knowing which learning strategies are most important for academic achievement suits both the student and the instructor.

A learning strategy can be defined as a mental activity, regulated by the student and that is linked to the understanding of the subject (Gloggler-Frey, Deutscher \& Renkl, 2018). Learning strategies correspond to a set of actions to solve 

Affective Strategies through application of the module "Learning to Learn" in University Students...

different tasks. These strategies may increase depending on complexity and are developed based on the usual methods of processing, control, regulation and evaluation of the information of their activities by the students (Chuvgunova \& Kostromina, 2016).

There are several perspectives on how learning strategies can be classified. In this regard, some classify them in cognitive, motivational and self-regulation strategies (Weinstein, Schulte \& Palmer, 1987). Others classify the strategies into cognitive, metacognitive and resource management (McKeachie et al., 1990). They can also be divided into deep, superficial and achievement strategies (Biggs, 1987). The classification of these strategies is diverse; however, there would be a consensus in three components: Cognitive, metacognitive and socioemotional strategies (O’Malley \& Chamot, 1990; Yang \& Bai, 2019).

Based on the theory of self-regulated learning, learning must occur as a cyclic interaction between cognitive processes and metacognitive processes. This idea comes from the conception that cognitive and metacognitive processes complement each other in their functions (Roelle, Nowitzki \& Berthold, 2017). Cognitive and socio-emotional strategies became the focus of attention in higher education research, then metacognitive strategies have been recognized as abilities that allow the application of cognitive and socioemotional strategies (Vermunt, 1996). Socio-emotional strategies are procedures performed by students in which they adopt and manage their interactions with environmental factors, or to control affective factors such as emotions and motivations (Yang \& Bai, 2019). While cognitive and socio-emotional strategies emphasize specific learning procedures, metacognitive strategies have a broader scope.

Figure 1 - Classification of Learning Strategies.

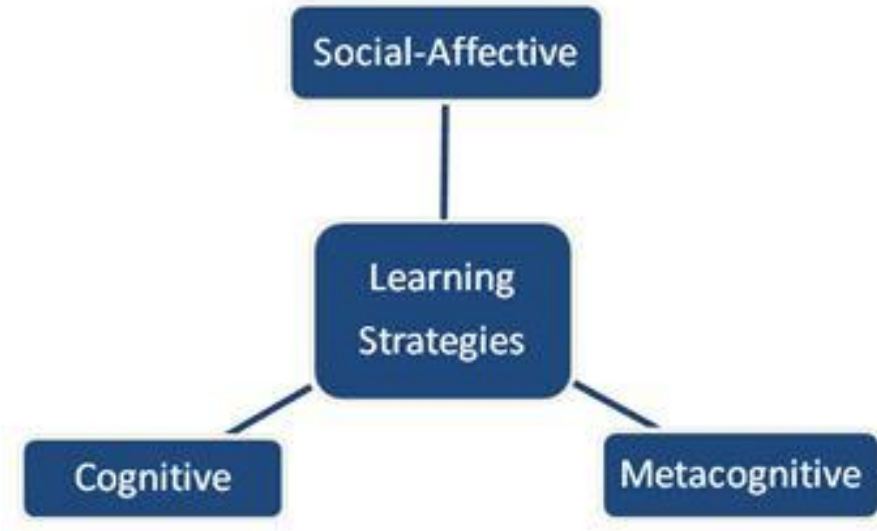

Source: Own design based on Yang \& Bai (2019).

\section{Cognitive Strategies}

Cognitive strategies are applied to study the learning material, that is: assimilate, combine, among others; provided that metacognitive strategies are applied to manage the learning process such as planning, controlling the result among others (Chuvgunova \& Kostromina, 
2016). Cognitive strategies include simple and complex strategies that are directly applicable to a given task or course (Alexander, Graham \& Harris, 1998).

Cognitive strategies are used to increase understanding and recall of particular information; so that the material is more meaningful for the students. They help the development of coherent mental schemes by imposing a structure on the information collected, allowing students to more easily integrate new information with existing knowledge (De Boer et al., 2018). Cognitive strategies are divided into several groups: elaboration strategies through which students create connections between new material and what is already known (Cromley, Snyder-Hogan \& LuciwDubas, 2010); essay strategies where students store information in memory repeating and remembering its content; and organizational strategies, where students classify and structure information (Mayer, 2008).

The cognitive strategies are formed by the acquisition strategies, information codification (or storage) and recovery (or evocation), conceived as a reproductive action, which serves as a basis for the basic development processes of the thinking (Román \& Gallego, 2008 ). This process translates an input sensory information, from one conceptual representation to another, and can even translate from a conceptual representation to an output motor information (Sternberg, 1997). It has also been found that Intensive use of cognitive strategies implies greater performance in fluid intelligence (Kaya \& Acar, 2019).

\section{Metacognitive Strategies}

The goal of metacognitive strategies is to teach students how to set goals and how to be effective and independent (Baker, 2002; Zhussupova \& Kazbekova, 2016). This is related to the way students think and learn, including planning, monitoring and evaluation skills (Baker \& Beall, 2009). Metacognitive strategies are implemented by students to plan to learn, monitor their activities and evaluate their results (O'Malley \& Chamot, 1990). They allow you to execute self-management or self-regulation to achieve the desired learning. Metacognitive strategies are more separate from learning tasks and, in general, are transferable through different tasks and learning domains (O'Malley \& Chamot, 1990). That would serve to ensure the proper functioning of the other groups of strategies, planning, supervising, directing, evaluating and adjusting the functioning of cognitive mechanisms (selfknowledge, self-management-regulationevaluation, self-management-planning) and 
the support strategies that favor or hinder the functioning of the other groups of strategies (Marugán et al., 2013; Zhang \& Seepho, 2013 ). In metacognitive strategies, students think about their thinking, this includes planning, monitoring of the understanding and modification of the mental processes themselves (Duncan \& McKeachie, 2005; Zimmerman, 2002). In recent studies, the effect size of metacognitive strategies on learning achievement was $r=0.20$ (Dent \& Koenka, 2016). This means that $4 \%$ of the total variance of students' academic is due to the use of metacognitive strategies (Cai et al., 2019).

Metacognitive strategies facilitate and regulate cognition. With these strategies, you can monitor and control your learning, including the application of cognitive strategies. Three phases characterize metacognitive activities. The first phase, called forecasting, addresses the planning strategies, that is, the students analyze the activities and plan how to approach it (De Boer et al, 2018). Then in the performance phase, the activity is executed, including monitoring strategies to verify the understanding of the material (Kostons, Van Gog \& Paas, 2010). The last phase of the learning process is selfreflection, in which a student evaluates the learning process, which provides information for planning the next learning task.

Metacognitive strategies are actions carried out by the subject, can be before, during and after the learning processes take place, to optimize the learning. It has three dimensions: Self-planning, self-monitoring (self-control) and self-evaluation (Moshman, 2018). In the literature, three types of metacognitive strategies are the most frequently used: self-planning, selfmonitoring, and self-evaluation (O'Malley \& Chamot, 1990; Pintrich, 1999; Weinstein \& Van Mater Stone, 1996; Zimmerman \& Martinez-Ponz, 1986).

\section{Social-affective Strategies}

In the case of social-affective strategies, it has been found that modifies the quality of verbalizations of coregulated activities and nonverbal behavior (Saariaho et al., 2019). Socio-emotional strategies are related to the ability to integrate thinking, feeling and behavior to achieve important goals (Zins et al., 2004). Through socio-emotional strategies, greater awareness and ability to regulate emotions, implement effective problemsolving strategies and build positive relationships in their environment are achieved.

A conceptual approach will be made about "learning to learn", which is 

Affective Strategies through application of the module "Learning to Learn" in University Students...

understood as the acquisition of skills and strategies that autonomously make possible future learnings. It involves paying special consideration to procedural contents (Gargallo, 2000). Learning to learn does not refer to the direct learning of contents, but the skills learning which helps students to learn content (Beltran, 1993). Learn to learn implies the capacity to consider how a person learns and accordingly to his acts, self-regulating its self-learning process through the use of flexible and appropriate strategies, that are transferred and adapted to new situations (Díaz \& Hernández, 1999 ). The learner must learn to search, select, analyze critically and integrate, in his cognitive schemes, the necessary information to develop successfully in the society.

An important question which comes to the mind would be, what strategy could be applied in order to help students to learn properly?, the interest in the subject is because today is essential that students "learn to learn", because, they will need to continue learning throughout their lives and, on the other hand, teachers forget about it and do not address problems to help students, professors only focus on teaching what is in the curricular of the state, neglecting teaching procedures for learning (strategies). To corroborate these approaches in the classrooms, this study is intended to verify the effects of the application of the learning to learn module in the learning strategies on the second term students of the Intercultural University of the Amazon in Pucallpa, Perú. This study is important because it will show teachers that apply learning strategies can help their students to learn properly and get better results in the learning process.

\section{Methods}

The research was quantitative, with an experimental design, with a sample of 120 students in the second term of the Aquaculture Agroforestry Engineering career at the University of the Amazon in Pucallpa, Perú. The procedures applied in the transfer of learning strategies were: Planning, motivation for use, modeling of the strategy, internalization of the strategy, independent practice, explicit instruction in processes of regulation and self-testing of learning and finally teaching in real contexts. Module I and II of learning to learn with 23 units were used for this purpose. The instrument used was the Scale of Learning Strategies (Román \& Gallego, 2008) and Inventory of Metacognitive Strategies (O’Neil \& Abedi, 1996). The application of the modules was done during two weekly hours, within the “Technical Writing” course. An ANOVA 
analysis was carried out, evaluating the influence that the application of the "Learning to Learn" module can have on Cognitive, Metacognitive and Socialaffective strategies in university students. The Analysis is for both the Experimental and Control groups and the strategies were evaluated before and after applying the learning strategies. Post-hoc tests are not applicable because these tests are to determine the individual effect of each factor when there are more than two, in this case, there are only two groups to compare. The software used for the analysis was SPSS version 25. Therefore, the proposed hypothesis was: The Application of the "Learning to Learn" module produces a significant improvement in students' learning strategies of the second term of the Aquaculture Agroforestry Engineering career at the University of the Amazon in Pucallpa.

\section{Results and discussion}

After the experiments had been done, the consolidated results of the research are presented in table 1.

Table 1. ANOVA of the difference of groups for learning strategies, with the Scale of learning strategies.

\begin{tabular}{ccccccc} 
Dimension & $\begin{array}{c}\text { Mean } \\
\text { Experimental }\end{array}$ & $\begin{array}{c}\text { Standard } \\
\text { Dev. }\end{array}$ & $\begin{array}{c}\text { Mean } \\
\text { Control }\end{array}$ & $\begin{array}{c}\text { Standard } \\
\text { Dev. }\end{array}$ & F & Significance $^{*}$ \\
\hline Cognitive & 126.81 & 13.99 & 124.13 & 11.82 & 0.230 & $\mathrm{p}(0.635)>0.05$ \\
\hline Metacognitive & 59.05 & 21.38 & 66.75 & 5.33 & 0.993 & $\mathrm{p}(0.320)>0.05$ \\
\hline Social/Affective & 29.95 & 10.64 & 32.00 & 3.21 & 0.281 & $\mathrm{p}(0.600)>0.05$ \\
\hline $\begin{array}{c}\text { Learning } \\
\text { Strategies }\end{array}$ & 215.81 & 38.21 & 222.88 & 14.88 & 0.254 & $\mathrm{p}(0.618)>0.05$ \\
\hline \multicolumn{7}{c}{ Significance level 0.05 } \\
\hline \multicolumn{7}{c}{ Source: Prepared by author. }
\end{tabular}

With the obtained data, in the experiment the acceptance of the null hypothesis for the variable: It means the application effect of the learning to learn module does not produce a significant improvement in the learning strategies in second term students of the National Intercultural University of the Amazon in Pucallpa [p $(0,618)>0.05]$. In other words, when applying the learning to learn module, students did not improve their learning strategies, consequently means that, between the two tests, the group of control had a better result on that dimension (as shown in table 1) than the experimental group, meaning that the module didn't cause an effect on this group.

The obtained results show that the learning to learn module did not make a significant difference in learning strategies, refute the postulates of Atkinson and Shiffrin (1968) on the processing and storage of information, that learning 

Affective Strategies through application of the module "Learning to Learn" in University Students...

strategies mediate this processing. Likewise, Nisbet and Shucksmith (1987); Weinstein, Goetz, and Alexander (1988) which are flexible processes that help in the proper use of learning strategies.

These results could be explained with the postulate of Wienstein et al., (1979), on the conceptual change of the role of learners in educational processes, where the interest of the research is centered on the information processing capacities of the students, which require more conscious training since due to the short time of this study it did not make it possible. Furthermore, the theory of information processing proposes that it is a complex and active process that the student does to achieve learning and that are aspects which current researches towards (Weinstein \& Meyer, 1986), this complexity in information processing requires other factors so that they can be transferred, one of these factors could be the maturation of people in cognitive processes (Darling, et al. 2019), because it is part of the personality of each person and not every person could be mature in cognitive processes, therefore, there is no control of that aspect and that is why this factor could influence in the study. The other factor would be the intrinsic motivation, because the students didn't find it interesting or exciting (the modules), so there was no motivation to have self-determination in order to put more effort in learning (Bieg, et al. 2016), this could be considered as other factor which could influence in this study.

On the other hand, Cooper (1993) considers learning as a problem of personal discovery, intrinsically motivated, in which the learner responds to environmental needs considering his style, self-regulation, and reflective learning; or as Coll et al., (1993) state, which is learned because we are capable of elaborating a personal representation of an object of reality or content that is intended to be learned from experience, interests and previous knowledge, but in the study, it was observed that students are still extrinsically motivated, for example, notes are their main motivation, and not so, the learning process itself. This approach focuses on learning as a personal discovery. Both positions point to autonomous learning until they become independent learners, the results show us the students in this research did not achieve autonomy in the process of self-learning, an aspect that must be deepened with other research.

It also refutes the empirical result found by Gargallo (2000), who succeeds in transferring learning strategies after applying for a program. These results in this context could also be the cause of the 
educational level in which the Ucayali region finds itself, which is in the last places in the comprehension tests at the national level at the basic level, which affects students who enter the higher level.

This controversy regarding the results invites us to continue investigating ways of transferring learning strategies, since, as the theory states, they would be tools that achieve autonomous learning, and this is a problem in our educational system, especially in the university education system where the student must investigate.

Despite the result of this study, the learning strategies can help students but they need to be applied in the right way so it can show effects after a period of time. The strategies could have a huge impact on the knowledge of the students, since, students would be able to learn properly with them. The learning strategies can help teachers also because, they would get better and expected results from their students.

This situation raises questions such as; how much time is needed to achieve the transfer of learning strategies? What other factors are at the root of the transfer of these strategies? Are our learners' autonomous learners? Questions that invite us to continue investigating the subject, and that open many possibilities to be able to answer it.

\section{Conclusion}

The application of the learning to learn module did not produce a significant improvement in the learning strategies in the second term students of the National Intercultural University of the Amazon in Pucallpa-Peru. This result refutes the postulate on the processing and storage of information, since they were not able to mediate the learning process, nor was improved the flexible use of these strategies. It can be explained by the conceptual change, since the capacities of information, processing needs a conscious and active training, for a longer time in its application, besides it requires other factors that could not be controlled as the cognitive and emotional maturation, because it is part of the personality of each person. Another aspect that interfered is the scarce development of intrinsic motivation. Likewise, the results are opposed to the findings of two empirical studies carried out in basic education. This indicates that the students have not yet become autonomous learners.

From the instructional point of view, it seems necessary that the teachers carry out exercises that allow students to be "active" subjects in their learning processes 
and strategies since the action of the student is defined as a relevant variable in the change of the conceptions. This aspect is closely related to the metacognitive activation and should help students to solve learning tasks or goals, to reflect on and solve their problems or difficulties of learning.

However, this study considers that the didactic strategy should be accompanied by certain contextual, motivational, and metacognitive conditions in the students, which allow them to develop a constructive vision of learning; this process should also orient them toward the required conceptual change since, otherwise, the student's perception may not correspond to the teacher's thoughts and intentions, and therefore, there may not be a relationship between instruction as perceived by the teacher and as perceived by the student. On the other hand, it is recommended that this study should be applied but in a longer period of time to see results in students, adding what was mentioned above.

Finally, it is necessary to emphasize that there are still many issues to investigate and deepen, both in terms of the analysis of conceptions about learning and in terms of cognitive, metacognitive and socio-affective strategies. It is hoped that this study will make an interesting contribution that will stimulate curiosity about the raising of new questions that will increase the understanding of these processes and, therefore, of what is related to human learning in the context of university education.

\section{References}

Alexander, P. A., Graham, S., \& Harris, K. R. (1998). A perspective on strategy research: Progress and prospects. Educational Psychology Review, 10(2), 129-154.

https://doi.org/10.1023/A:102218550299 $\underline{6}$

Atkinson, R., \& Shiffrin, R. (1968). Human memory: a proposed system and its control processes. In Spence, K. W., \& Spence, T. J. (Series Ed.). The psychology of learning and motivation Series: Vol. 2. (pp. 89-195). https://doi.org/10.1016/S0079$\underline{7421(08) 60422-3}$

Ablard, K. E., \& Lipschultz, R. E. (1998). Self-regulated learning in high-achieving students: Relations to advanced reasoning, achievement goals, and gender. Journal of Education Psychology, 90(1), 94-101. http://dx.doi.org/10.1037/00220663.90.1.94

Baker, L. (2002). Metacognition in comprehension instruction. In Block, C. C., \& Pressley, M. (Eds.). Comprehension instruction: Research-based best practices (pp. 77-95). New York: Guilford Press.

Baker, L., \& Beall, L. C. (2009). Metacognitive processes and reading comprehension. In Israel, S. E., \& Duffy, G. G. (Eds.). Handbook of research on reading comprehension (pp. 373-388). New York: Routledge. 
Beltran, J. (1993). Procesos, estrategias y técnicas de aprendizaje. Madrid: Síntesis Editorial.

Bembenutty, H., \& Zimmerman, B. J. (2003). The relation of motivational beliefs and self-regulatory processes to homework completion and academic achievement. Annual Meeting of American Education Research Association, Chicago, IL.

Bieg, S., Reindl, M., \& Dresel, M. (2016). The relation between mastery goals and intrinsic motivation among university students: a longitudinal study. Educational Psychology, 37(6), 666-679. http://dx.doi.org/10.1080/01443410.2016.1 $\underline{202403}$

Biggs, J. B. (1987). Student approaches to learning and studying. Hawthorn. Victoria: Australian Council for Educational Research.

Braten, I., \& Olaussen, B. S. (1998). The learning and study strategies of Norwegian first-year college students. Learning and individual Differences, 10(4), 309-327. https://doi.org/10.1016/S1041-

$\underline{\text { 6080(99)80125-3 }}$

Cai, Y., King, R. B., Law, W., \& McInerney, D. M. (2019). Which come first? Modeling the relationships among future goals, metacognitive strategies and academic achievement using multilevel cross-lagged SEM. Learning and Individual Differences, 74, 1-12. https://doi.org/10.1016/j.lindif.2019.06.004

Carr, M., \& Jessup, D. L. (1995). Cognitive and metacognitive predictors of mathematics strategy use. Learing and Individual Differences, 7(3), 235-4-247. https://doi.org/10.1016/1041$\underline{6080(95) 90012-8}$

Chalupa, M. C., \& Charles, T. (2001). An analysis of college student's motivation and learning strategies in computer courses: A cognitive view. Delta Pi Epsilon Journal, 43(4), 185-199.

Chamot, A. U. (1987). The learning strategies of ESL students. In Wenden, A. L., \& Rubin, J. (Eds.). Learner strategies in language learning (pp. 71-78). New York: Prentice Hall.

Chen, C. C. (2002). Self-regulated learning strategies and achievement in an introduction to information system course, Information Technology, Learning, and Performance Journal, 20(1), 11-23.

Chuvgunova, O., \& Kostromina. S. (2016). Planning as a learning skill of students. Procedia - Social and Behavioral Sciences, 217, 132-138. https://doi.org/10.1016/j.sbspro.2016.02.04 $\underline{5}$

Coll, C., Martin, E., Mauri, T., Miras, M., Onrubia, J., \& Zabala, A. (1993). El constructivismo en el aula. Barcelona: Argó.

Cooper, P. (1993). Paradigm Shifts in Designed Instruction: From Behaviorism to Cognitivism to Constructivism. Educational Technology, 33(5), 12-19.

Cromley, J. G., Snyder-Hogan, L. E., \& Luciw-Dubas, U. A. (2010). Reading comprehension of scientific text: A domain-specific test of the direct and inferential mediation model of reading comprehension. Journal of Educational Psychology, 102(3), 687-700. http://dx.doi.org/10.1037/a0019452

Darling L., Flook, L., Cook, Ch., Barron, B., \& Osher, D. (2019). Implications for educational practice of the science of learning and development, Applied Developmental Science, 24(2), 97-140. https://doi.org/10.1080/10888691.2018.15 $\underline{37791}$ 
De Boer, H., Donker, A. S., Kostons, D. D., N. M., \& Van der Werf, G. P. C. (2018). Long-term effects of metacognitive strategy instruction on student academic performance. Educational Research Review, 24, 98-115. https://doi.org/10.1016/j.edurev.2018.03.0 $\underline{02}$.

Dent, A. L., \& Koenka, A. C. (2016). The Relation Between Self-Regulated Learning and Academic Achievment Across Childhood and Adolescence: A MetaAnalysis. Educational Psychology Review, 28(3), 425-474. https://doi.org/10.1007/s10648-0159320-8

Díaz, B. A., \& Hernández, G. (1998). Estrategias docentes para un aprendizaje significativo. Una interpretación constructivista. Distrito Federal: McGraw-Hill.

Duncan, T. G., \& McKeachie, W. J. (2005). The making of the Motivated Strategies for Learning Questionnaire. Educational Psychologist, 40(2), 117128.

https://doi.org/10.1207/s15326985ep4002 6

Gargallo, B. (2000). Procedimientos. Estrategias de aprendizaje. Su naturaleza, enseñanza y evaluación. Valencia: Tirant Lo Blanch.

Glogger-Frey, I., Deutscher, M., \& Renkl, A. (2018). Student teachers' prior knowledge as prerequisite to learn how to assess pupils' learning strategies. Teaching and Teacher Education, 76, 227-241.

https://doi.org/10.1016/j.tate.2018.01.012

Halbach, A. (2000). Finding out about student's learning strategies by looking at their dairies: A case study. System, 28(1),
85-96. $\quad$ https://doi.org/10.1016/S0346251X(99)00062-7

Kaya, F., \& Acar, S. (2019). The impact of originality instructions on cognitive strategy use in divergent thinking. Thinking Skills and Creativity, 33, 1-11. https://doi.org/10.1016/j.tsc.2019.100581

Kostons, D., Van Gog, T., \& Paas, F. (2010). Self-assesment and task selection in learner-controlled instruction: Differences between effective and ineffective learners. Computers \& Education, 54(4), 932-940. https://doi.org/10.1016/j.compedu.2009.09. $\underline{025}$

Marugán, M., Martín, L. J., Catalina, J., \& Román J. M. (2013). Estrategias cognitivas de elaboración y naturaleza de los contenidos en estudiantes univesitarios. Psicología Educativa, 19(1), 13-20. http://dx.doi.org/10.5093/ed2013a3

Mayer, R. E. (2008). Learning and Instruction (2nd Edition). New Jersey: Pearson Merrill Prentice Hall.

McKeachie, W. J., Pintrich, P. R., Lin, Y. G., Smith, D. A. F., \& Sharma, R. (1990). Teaching and Learning in the college classroom. A review of the research literature. Michigan: University of Michigan

Moshman, D. (2018). Metacognitive theories. Educational Psychology Review, $30(2)$, 599-606. https://doi.org/10.1007/s10648-0179413-7

Neroni, J., Meijs, C., Gijselaers, H. J. M., Kirschner, P. A., \& de Groot, R. H. M. (2019). Learning strategies and academic performance in distance education. Learning and Individual Differences, 73, 1-7.

https://doi.org/10.1016/j.lindif.2019.04.007 
Nisbet, J., \& Shucsmith, J. (1987). Estrategias de aprendizaje. Madrid: Santillana.

O'Malley, J. M., \& Chamot, A. U. (1990). Learning strategies in second language acquisition. Cambridge: Cambridge University Press. https://doi.org/10.1017/CBO97811395244 $\underline{90}$

O'Neil, H. F., \& Abedi, J. (1996). Reliability and validity of a state metacognitive inventory: Potential for alternative assessment. The Journal of Educational Research, 89(4), 234 - 245. https://doi.org/10.1080/00220671.1996.99 $\underline{41208}$

Pintrich, P. R. (1999). The role of motivation in promoting and sustaining self-regulated learning. International Journal of Educational Research, 31(6), 459-470. https://doi.org/10.1016/S08830355(99)00015-4

Roelle, J., Nowitzki, C., \& Berthold, K. (2017). Do cognitive and metacognitive processes set the stage for each other? Learning and Instruction, 50, 54-64. https://doi.org/10.1016/j.learninstruc.2016. 11.009

Román, J. M., \& Gallego, S. (2008). Manual ACRA Escala de estrategias de aprendizaje. Madrid: TEA.

Saariaho, E., Toom, A., Soini, T., Pietarinen, J., \& Pihältö, K. (2019). Student teachers' and pupils' co-regulated learning behaviours in authentic classroom situations in teaching practicums. Teaching and Teacher Education, 85, 92-104. https://doi.org/10.1016/j.tate.2019.06.003

Sternberg, R. J. (1997). Cognitive conceptions of expertise. In: Feltovich, P., Ford., K. M., \& Hofmann, R. R. (Eds.). Expertise in context. Human and machine (pp. 149-162). Menlo Park: AAAI Press.
Vermunt, J. D. (1996). Metacognitive, cognitive and affective aspects of learning styles and strategies: A phenomenographic analysis. Higher Education, 31(1), 25-50. https://doi.org/10.1007/BF00129106

Weinstein, C. E., Schulte, A. C., \& Palmer, D. R. (1987). The Learning and Study Strategies Inventory. Florida: $\mathrm{H} \& \mathrm{H}$ Publishing.

Weinstein, C. E., Goetz, E. T., \& Alexander, P. A. (Eds.). (1988). Learning and study strategies: Issues in assessment, instruction, and evaluation. San Diego: Academic Press.

Weinstein, C. E., \& Van Mater Stone, G. (1996). Learning strategies and learning to learn. In De Corte, E., \& Weinert, F. E. (Eds.). International encyclopedia of developmental and instructional psychology (pp. 419-423). New York: Pergamon.

Weinstein, C. E., \& Meyer, D. K. (1986). The teaching of learning strategies. In Wittrock, M. C. (Ed.). Handbook of research on teaching (pp. 315-327). New York: Macmillan.

Weinstein, C. E., Underwood, V. L., Wicker, F. E., \& Cubberly, W. E. (1979). Cognitive learning strategies: verbal and imaginal elaboration. In Spielberger, C. D. (Ed.). Cognitive and affective learning strategies (pp. 45-75). New York: Academic Press.

Yang, C., \& Bai, L. (2019). The use of metacognitive strategies by Chinesse $\mathrm{PhD}$ students of social sciences in Australian universities. International Journal of Educational Research, 97, 43-52. https://doi.org/10.1016/j.ijer.2019.06.007

Zhang, L., \& Seepho, S. (2013). Metacognitive Strategy Use and Academic Reading Achievement: Insights from a 
Chinese Context. Electronic Journal of Foreign Languange Teaching, 10(1), 5469.

Zimmerman, B. J. (2002). Becoming a self-regulated learner: An overview. Theory Into Practice, 41(2), 64-70. https://doi.org/10.1207/s15430421tip4102 $\underline{2}$

Zimmerman, B. J., \& Martínez-Pons, M. (1990). Student differences in selfregulated learning: Relating grade, sex, and giftedness to self-efficacy and strategy use. Journal of Educational Psychology, 82(1), 51-59. http://dx.doi.org/10.1037/0022$\underline{0663.82 .1 .51}$

Zins, J. E., Bloodworth, M. R., Weissberg, R., \& Walberg, H. J. (2007). The Scientific Base Linking Social and Emotional Learning to School Success. Journal of Educational and Psychological Consultation, $\quad$ 17(2-3). https://doi.org/10.1080/104744107014131 $\underline{45}$

Zhussupova, R., \& Kazbekova, M. (2016). Metacognitive strategies as points in teaching reading comprehension. Procedia - Social and Behavioral Sciences, 228, 593-600.

https://doi.org/10.1016/j.sbspro.2016.07.09 $\underline{1}$

\section{Article Information \\ Received on November 21th, 2020 \\ Accepted on April 07th, 2020 \\ Published on July, 29th, 2020}

Author Contributions: The author were responsible for the designing, delineating, analyzing and interpreting the data, production of the manuscript, critical revision of the content and approval of the final version published.

Conflict of Interest: None reported.

Orcid

William Gil Castro Paniagua

iD http://orcid.org/0000-0001-5817-8053

Abdias Chávez Epiquén

iD http://orcid.org/0000-0001-5589-5217

Dulio Oseda Gago

D.tp://orcid.org/0000-0002-3136-6094

How to cite this article

APA

Castro Paniagua, W. G., Chávez Epiquén, A., \& Oseda Gago, D. (2020). Effects of Cognition, Meta-Cognition and Social Affective Strategies through application of the module "Learning to Learn" in University Students. Rev. Bras. Educ. Camp., 5, e7967. http://dx.doi.org/10.20873/uft.rbec.e7967

ABNT

CASTRO PANIAGUA, W. G.; CHÁVEZ EPIQUÉN, A.; OSEDA GAGO, D. Effects of Cognition, Meta-Cognition and Social Affective Strategies through application of the module "Learning to Learn" in University Students. Rev. Bras. Educ. Camp., Tocantinópolis, v. 5, e7967, 2020. http://dx.doi.org/10.20873/uft.rbec.e7967 